\title{
LA RESPONSABILIDAD DEL ESTADO OCASIONADA POR EL RIESGO O VICIO DE LAS COSAS
}

\author{
Pablo Esteban Perrino ${ }^{1}$
}

RESUMEN: El autor a partir de la revisión acuiciosa, primero de la doctrina y luego de la jurisprudencia, propone una revisión del sistema de responsabilidad del Estado por el riesgo o vicio de las cosas en el campo del Derecho Administrativo argentino con proposiciones específicas, especialmente la de limitar el campo de atribución de riesgo.

Palabras Clave: Responsabilidad estatal - Daños - Riesgo - Factor de atribución.

\section{Responsibility OF THE STATE CAUSEd By VICE OR RISK OF THINGS}

ABSTRACT: The author proposes, beginning with a detailed review, first of the doctrine and then of the jurisprudence, a revision of the responsibility system of the State brought about by risk or vice in things in the area of Argentinean Administrative Law with specific proposals, especially to limit the spectrum of attribution of risk. factor.

KEY wORDS: State responsibility - Damages - Risk - Attribution

SUMARIO: I. Introducción. II. Características del régimen argentino de responsabilidad. 1) Origen y desarrollo pretoriano. 2) Influencia del Derecho europeo. 3) Responsabilidad directa. 4) La regulación de la responsabilidad es de competencia nacional y provincial. 5) Requisitos para que surja el deber

Profesor de Derecho Administrativo de la Facultad de Ciencias Jurídicas y Sociales de la Universidad Nacional de La Plata, de la Facultad de Derecho y Ciencias Políticas de la Universidad Católica Argentina, de la Facultad de Derecho de la Universidad Austral, y de la Facultad de Derecho y Ciencias Sociales de la Universidad de Buenos Aires. Secretario del Instituto de Derecho Administrativo de la Academia Nacional de Derecho y Ciencias Sociales. Subdirector de la Revista de Derecho Administrativo, que dirige Juan Carlos Cassagne y edita LexisNexis-Depalma. Socio del estudio Cassagne Abogados. Con juez de la Cámara Nacional de Apelaciones en lo Contencioso Administrativo Federal. Correo electrónico: pperrino@cassagne.com.ar

Artículo recibido el 03 de mayo de 2005. Aprobado por el Comité Editorial el 29 de agosto de 2005. 
de responder del Estado. III. La responsabilidad por riesgo. 1) Origen y fundamentos. 2) ¿Quiénes responden? 3) Naturaleza de la obligación de resarcir. 4) Eximentes de responsabilidad. IV. Aplicación judicial del factor riesgo a la responsabilidad estatal. 1) Daños provocados por la caída de árboles. 2) Daños ocasionados por el mal estado de aceras, calles y rutas. 3) Trampolines instalados por un municipio en una playa que ocasionan daños a un bañista. 4) Perjuicios producidos a raíz de la caída de parte de la mampostería de un monumento público y la demolición de un inmueble. 5) Perjuicios ocasionados por el mal funcionamiento de ascensores en edificios públicos. 6) Daños provocados por explosivos. 7) Daños provocados por el uso de armas de fuego por parte de policías o integrantes de fuerzas de seguridad, aún en franco de servicio. 8) Perjuicios ocasionados a raíz de la muerte de un menor producida por la utilización de un muelle en mal estado. 9) Daños producidos por la circulación de automotores oficiales. 10) Red de vólley colocada peligrosamente. $V$. Algunas reflexiones acerca de la aplicación de la teoría del riesgo a la responsabilidad estatal 1) Reflexiones comunes a los daños originados por sujetos públicos o privado. Amplio alcance del art. $1113,2^{\circ}$ párrafo, $2^{\alpha}$ parte, del Código Civil. 2) Reflexiones respecto de la responsabilidad estatal por riesgo VI. La Teoría del Riesgo y la responsabilidad estatal derivada de la actividad de los concesionarios de servicios y de obras públicas. VII. Colofón: Necesidad de limitar el campo de acción del factor de atribución riesgo.

\section{INTRODUCCIÓN}

En este trabajo nos proponemos efectuar algunas reflexiones sobre un aspecto puntual de la responsabilidad estatal como es la forma en que se aplica la teoría del riesgo creado (art. $1113,2^{\circ}$ párrafo, $2^{a}$ parte del Código Civil) en el caso de daños ocasionados por cosas de propiedad del Estado o que están bajo su guarda, como también por actividades estatales que pueden crear situaciones de riesgo o peligro.

Se trata de una faceta de la responsabilidad de los poderes públicos a la que la doctrina administrativista ${ }^{2}$ le ha prestado poca atención, que comprende supuestos muy vastos y de diversas características y que usualmente es abordada por los tribunales con arreglo a lo dispuesto en la legislación civil.

Para la adecuada comprensión del tema que aquí abordaremos, es conveniente recordar previa y sucintamente las características de nuestro régimen de responsabilidad estatal y la forma en que ha sido recep-

2 El único trabajo específico que nosotros conocemos en el que se examina con detenimiento esta cuestión ha sido elaborada por un profesor de derecho civil, como es el Dr. Marcelo J. López Mesa, La doctrina del riesgo creado y su posibilidad de aplicación al Estado, Revista de Derecho Administrativo, $\mathrm{N}^{\circ} 27 / 29$, p. 435 y ss. 
tada el factor de atribución riesgo en el Código Civil y su aplicación judicial.

\section{CaRACTERíSTICAS DEL RÉGIMEN ARGENTINO DE RESPONSABILIDAD}

\section{1) Origen y desarrollo pretoriano}

Al igual que ha ocurrido en numerosos países europeos, como Francia ${ }^{3}$, Italia ${ }^{4}$ y Alemania ${ }^{5}$, en nuestro país la formulación de nuestro sistema de responsabilidad ha sido una laboriosa conquista fruto de la jurisprudencia ${ }^{6}$ y de los aportes de la doctrina.

La falta de disposiciones constitucionales y de un cuerpo legal específico que regule la responsabilidad del Estado (tal el caso de España y los Estados Unidos) no ha constituido un valladar para que por vía pretoriana, con sustento, principalmente, en las cláusulas del texto constitucional que garantizan la inviolabilidad del derecho de propie$\operatorname{dad}^{7}$ (arts. 14 y 17), el art. 19 que "establece el principio general que

3 De Laubadère, André Traité de Droit Administratif, huiieme édition, Librairie Genérale de Droit y Jurisprudence", París, 1980, p. 693; MOREAU, Jacques, Evolución reciente de la responsabilidad de la Administración en el Derecho francés, Documentación Administrativa $\mathrm{n}^{\circ}$ 239, p. 175 y ss., Rougevin-Baville, Michel, La responsabilité administrative, Hachette, París, 1992, p. 9 y ss. Sempé, Francoise, La responsabilidad extracontractual de la Administración en Francia, en la obra colectiva, Propiedad, expropiación y responsabilidad. La garantía indemnizatoria en el Derecho europeo y comparado, editado por Tecnos y la Junta de Andalucía, Madrid, 1995, p. 969 y ss.

4 Clarich, Marcello, La responsabilidad de la Administración Pública en el ordenamiento italiano: caracteres generales y tendencias recientes, en la obra colectiva antes citada Propiedad, expropiación $y$ responsabilidad. La garantía indemnizatoria en el Derecho europeo y comparado, p. 1005 y ss.

5 OssenbüHL., Fritz, "La responsabilidad patrimonial de los poderes públicos en la República Federal de Alemania", en la obra colectiva antes citada. Propiedad, expropiación y responsabilidad. La garantía indemnizatoria en el Derecho europeo y comparado", p. 931 y ss.

6 Ver: Reiriz, María Graciela, Responsabilidad del Estado, Eudeba, Bs. As., 1969, p. 83 y ss.; Cassagne, Juan Carlos, Derecho Administrativo, $7^{a}$ ed. LexisNexis Abeledo-Perrot, Bs. As., t. I, cap. V, .Uslenghi, Alejandro J., Lineamientos de la responsabilidad del Estado por actividad ilícita, obra colectiva Responsabilidad del Estado y del funcionario público, Ciencias de la Administración, Bs. As., 2001, p. 49 y ss. y PERrino, Pablo E. La responsabilidad extracontractual en el derecho argentino, R.A.P. $\mathrm{n}^{\circ} 237$, ps. 9/14.

7 Conf. Fallos: 253:316; 274:432; 277:225; 300:143; 301:403, 302:159; 305:1045 entre otros. La Corte nacional también ha fundado la responsabilidad estatal, en antiguos pronunciamientos de principios del siglo XX, en postulados de justicia y equidad (Fallos: 111:107 y 129:5). Cabe destacar, que el primer trabajo en el que se fundó la responsabilidad estatal en la protección de los derechos constitucionales fue el de Rodolfo Bullrich, intitulado La responsabilidad del Estado, publicado en el año 1920. En la misma línea Miguel S. Marienhoff sostenía que el fundamento de la responsabilidad estatal "no es otro que el Estado de derecho y sus postulados". A su juicio, de esos principios de base constitucional, que tienden a lograr la seguridad jurídica y el respeto del derecho de los administrados, surge el fundamento de la responsabilidad estatal en el campo del derecho público (Tratado de derecho administrativo, Abeledo-Perrot, Bs. As., 1980, t. IV, p. 699). 
prohíbe a los hombres perjudicar los derechos de un tercero: alterum non laedere" 8 y el art. 16 que consagra el principio de igualdad en las cargas públicas $^{9}$, se sentaran las bases de una doctrina judicial que reconoce ampliamente el resarcimiento de los daños causados injustamente por cualquiera de los poderes del Estado.

Sin embargo, nuestro derecho carece de un tratamiento normativo sistemático y unitario de la responsabilidad estatal. A diferencia de lo que acontece en otros sistemas jurídicos, en el ordenamiento jurídico argentino -tanto nacional como provincial-, no existe, al menos con carácter general, una regulación orgánica sobre este instituto. Solo en áreas específicas y respecto de aspectos muy puntuales, la Nación y las provincias $^{10}$ han dictado normas ${ }^{11}$.

Ante la falta de una legislación específica durante mucho tiempo se sustentó el deber de reparar del Estado derivada de su actuación ilícita en las disposiciones del Código Civil concernientes a la responsabilidad

8 Fallos: 308:118; 320:1999 y CSJN, causa A. 2652. XXXVIII. "Aquino, Isacio c/ Cargo Servicios Industriales S.A. s/ accidentes ley 9688", sent. del 21/9/04, JA, 2004-IV, p. 16.

9 La Corte Suprema de Justicia de la Nación ha invocado este principio constitucional para fundamentar el deber de responder del Estado por actos válidos. Así ha expresado que el fundamento de la obligación del Estado de resarcir ciertos daños que guarden relación de causalidad con el ejercicio regular de sus poderes propios se halla, en última instancia, en el beneficio que toda la comunidad recibe de las acciones que el Estado promueve por el interés general y cuyas consecuencias eventualmente dañosas no es justo que sean soportadas exclusivamente por un individuo o grupo limitado -más allá de un límite razonable-sino que debe redistribuirse en toda la comunidad a fin de restablecer la garantía consagrada en el art. 16 de la Constitución Nacional (Fallos: 315:1892; 321:3363; conf. Fallos: 293:617, voto concurrente del Dr. Levene y Fallos:316:1335, voto disidente del Dr. Barra).

10 Son numerosas las constituciones provinciales que contienen previsiones básicas sobre la cuestión bajo examen (Vgr. constituciones provinciales de Misiones (art. 80), Santa Fe (art. 18), Catamarca (arts. 47 y 48), San Juan (art. 43), Salta (art. 5), Jujuy (art. 10), Córdoba (art. 14), La Rioja (art. 48), Chaco (art. 72), Río Negro (art. 55), Formosa (art. 25), Tierra del Fuego (art. 188)) y también las que contemplan la obligación de indemnizar los perjuicios irrogados por sentencias condenatorias erróneas de (Vgr. constituciones provinciales de Córdoba (art. 42, párrafo $2^{\circ}$ ), Chaco (art. 24), Chubut (art. 28), Formosa (art. 22), Jujuy (art. 29, inc, 11), La Pampa (art. 11), Misiones (art. 27), Neuquén (art. 40), Río Negro art. 19), Salta (art. 5), Santa Cruz (art. 29), Santa Fe (art.9, párrafo $6^{\circ}$ ) y Tierra del Fuego (art.40)).

11 Tal como ocurre por ejemplo, en los siguientes supuestos: 1) responsabilidad derivada de incumplimientos contractuales (por ejemplo: arts. 62, inc. a, art. 64, inc. b de la ley 6021 (t.o. por decreto 536/95), Obras Públicas de la provincia de Buenos Aires; arts. 71 del decreto 3300/72, Reglamento de Contrataciones de la provincia de Buenos Aires; art. 9 , incs. a y c de la ley 9254, Concesión de obras públicas provinciales, y art. 11, incs. a y b) ley 9645 , Concesión de obras públicas municipales), 2) daños causados en el marco de la relación de empleo público (Ley 11.757, Estatuto del empleado municipal (arts. 9, inc. b.2, último párrafo; y 24), Ley 11.758, Sistema provincial de la profesión administrativa (art, 30); decreto-ley 9550 (t.o. 1995), del personal de la policía bonaerense (art. 116, inc. e); Ley 19.101, modificada por la ley 22.511, orgánica de las Fuerzas Armadas; 19.349, modificada por ley 22.534 Orgánica de la Gendarmería Nacional, ley 12.992, con sus modificatorias, leyes 20.281 y 23.028, orgánica de la Prefectura Naval), 3) perjuicios producidos por error judicial en materia penal (Art. 10 del Pacto de San José de Costa 
por culpa (art. 1109) y por el hecho de los dependientes (art. 1113, $1^{\circ}$ párraf.).

Tal solución -loable en su momento, ya que posibilitó responsabilizar al Estado por los perjuicios que ocasionaba- actualmente se presenta como una salida equivocada, porque salvo los daños provocados por comportamientos estatales en relaciones de derecho privado, la responsabilidad de los poderes públicos constituye un instituto de corte claramente iuspublicístico, cuya autonomía respecto de las normas del derecho privado fue reconocida por el Tribunal de Conflictos francés en 1873 en el famoso caso "Blanco" 12 .

De ahí que, hoy en día, ante la falta de una normativa en la materia, si bien se sigue acudiendo a la legislación civil para resolver los problemas que presenta la responsabilidad estatal, se lo hace (o mejor dicho se lo debe hacer) de manera analógica ${ }^{13}$, es decir, produciendo la adaptación de las soluciones previstas en el derecho privado al ámbito público y no de manera directa o subsidiaria.

\section{2) Influencia del Derecho europeo}

El sistema argentino de responsabilidad tiene una clara filiación europea, en particular respecto del Derecho francés y, en menor medida, del italiano.

En efecto, al igual que en Francia, la Administración Pública responde, fundamentalmente, por los daños derivados de la existencia de una falta de servicio, por el riesgo creado y por la violación al principio de igualdad ante las cargas públicas ${ }^{14}$. Esto último, es lo que en Argentina se identifica, siguiendo la tradición italiana, como responsabilidad por actividad lícita o válida.

A su vez, la influencia italiana se advierte también por el distinto alcance de la reparación que corresponde otorgar de acuerdo a la causa

Rica, norma de jerarquía constitucional a tenor de lo dispuesto en el art. 75, inc. 22 de la Constitución nacional y también en numerosas constituciones provinciales; art. 488 del Código Procesal Penal de la Nación y art. 477 del Código Procesal Penal de la Provincia de Buenos Aires) 4) daños generados por requisiciones de bienes por razones de seguridad (art. 34 de la ley 23.554, de Defensa Nacional).

12 Sent. 8/2/1873, Rec. Lebon, 1er. suppl. p. 61, concl. David; DP, 1973.3.17; S., 1973.2.153.

13 Fallos: 300:143; 304:721; 308:451 y 318:1959. Ello es así, salvo respecto del art. 1112 del Código Civil, pues al establecer dicha norma la responsabilidad de los funcionarios por su obrar irregular, y fundarse en ella la responsabilidad estatal por falta de servicio, su aplicación debe ser directa (Perrino, Pablo E., Los factores de atribución de la responsabilidad extracontractual del Estado por su actividad ilícita, obra colectiva Responsabilidad del Estado $y$ del funcionario público, Ciencias de la Administración, Buenos Aires, 2001, p. 59 y ss.). Sin embargo, la Corte Nacional ha expresado en varias ocasiones que tal precepto se aplica por vía subsidiaria (Fallos: 306:2030; 312:1656; 318:193; 320:266, entre otros).

14 Rivero, Jean y Waline, Jean, Droit administratif, $17^{\mathrm{e}}$ ed., Dalloz, Paris, 1998, ps. 268 y ss. 
de los daños. En efecto, si bien median decisiones judiciales ${ }^{15}$ y opiniones doctrinales encontradas ${ }^{16}$, tradicionalmente se ha sostenido que el quantum indemnizatorio en los supuestos de responsabilidad estatal por actividad lícita, ante la falta de normas que lo establezcan ${ }^{17}$ y dado su carácter cuasi expropiatorio, se limita al pago del daño emergente y no al lucro cesante ${ }^{18}$.

15 El estudio de los fallos de la Corte Suprema de Justicia de la Nación pone de relieve que no siempre ha seguido un criterio homogéneo en esta materia. En efecto, pueden advertirse dos grandes posiciones: una restringida que ciñe esa indemnización al daño emergente (Fallos: 195:66; 293:617, 301:403; 312: 649; 320:568, disidencia del juez Vázquez, entre otros), y otra amplia que comprende, además, el lucro cesante (J.A., 1965-VI-362; Fallos: $286: 333 ; 306: 1409 ; 312: 2266$, entre otros). Sin embargo, en los últimos tiempos el alto tribunal ha dictado numerosos pronunciamientos en los cuales se ha condenado al pago de los rubros daño emergente y lucro cesante por daños ocasionados por el obrar estatal lícito (Fallos:316:1335;:318:1440; 320:2551; 326640, entre otros).

16. Así en lo que se refiere a la revocación de un acto o contrato administrativo por razones de oportunidad, mérito o conveniencia la doctrina no es pacífica acerca del alcance de la indemnización. Para algunos solo corresponde un resarcimiento acotado al daño emergente. Para esta postura, ante la falta de una norma que contemple la cuestión cabe aplicar los principios de la expropiación para todos los supuestos en los que un comportamiento lícito del Estado lesione derechos de los administrados, causándoles perjuicios que no están obligados a soportar. Sobre esa base, con arreglo a lo dispuesto en el art. 10 de la ley de expropiaciones 21.499 , concluyen que no corresponde indemnizar el lucro cesante. Asimismo, señalan que en la Constitución Nacional no existe ninguna disposición que consagre el principio de integralidad del resarcimiento (Conf. Miguel S. MARIENHOFF, El lucro cesante en las indemnizaciones a cargo del Estado, ED 114-949; Nuevamente acerca del lucro cesante en las indemnizaciones a cargo del Estado; J.C. CASSAGNe, Derecho Administrativo, cit., t. I, p. 515; Julio R. Comadira, Derecho Administrativo. Acto administrativo. Procedimiento administrativo. Otros estudios, $2^{\text {a }}$ ed. act. y ampl. Bs. As., 2003, p. 377 y ss.), p. 4$\} 399$ y ss.; y Tomás Hutchinson, La Responsabilidad del Estado por la revocación del contrato administrativo por razones de interés público, en obra colectiva Contratos Administrativos, Ciencias de la Administración, Buenos Aires, 2000, p. 535 y ss.). Por el contrario, otros autores consideran que cuando la Administración revoca un acto o un contrato administrativo por razones de oportunidad corresponde un resarcimiento pleno de los perjuicios (daño emergente y lucro cesante). A su entender, la falta de texto legal expreso que establezca que en tales casos la indemnización es limitada no permite efectuar una aplicación general por vía de la analogía de las disposiciones de la ley de expropiaciones. Además, alegan que de lo contrario se lesionaría el derecho de propiedad amparado constitucionalmente (arts. 14 y 17) (conf. Elías P. GuAstavino, Indemnizaciones por la actividad lícita lesiva del Estado, ED, 118-190; Miguel A. BERCAITz, Teoria general de los contratos administrativos, $2^{a}$ ed., Buenos Aires, 1980, ps. 502/503; Rodolfo C. BARRA, Responsabilidad del Estado por revocación unilateral de sus actos y contratos, ED 122-861; Alberto B. BIANCHI, Nuevos alcances en la extensión en la responsabilidad del Estado, E.D., 111-550 y Requisitos de procedencia de la responsabilidad estatal por actividad legislativa, Revista de Administración Pública, Ciencias de la Administración, Buenos Aires, p. 9; Eduardo Mertehikian, La responsabilidad pública, Abaco, Bs. As., 2001, p131 y ss.

17 A partir del año 2000 este criterio restrictivo ha sido receptado en el orden nacional a través de numerosas normas dictadas en supuestos de revocación de actos y contratos administrativos por razones de oportunidad, mérito o conveniencia (art, 96 del decreto 436/2000; art.12 del decreto 1023/2001; art. 26 ley 25.344, art. 11 ley 25.453).

18 Ver: Marienhoff, Miguel S., El lucro cesante en las indemnizaciones a cargo del Estado, ED, 114-949 y Nuevamente acerca del lucro cesante en las indemnizaciones a cargo del Estado, LL, 


\section{3) Responsabilidad directa}

La responsabilidad estatal es directa, ya que no funciona como un sistema de cobertura de los perjuicios causados por los actos y hecho de los funcionarios públicos.

Cabe recordar que, hasta el año 1984 la Corte nacional sostuvo la tesis contraria, ya que entendía aplicable el art. $1113,1^{\circ}$ párraf. del Código. Civil que regula la responsabilidad por el hecho de los dependientes ${ }^{19}$. A fines de ese año al fallar el caso conocido caso "Vadell" 20 , siguiendo las enseñanzas de la doctrina administrativista ${ }^{21}$, modificó su postura y sostuvo que la responsabilidad estatal es siempre directa y no refleja o indirecta. Ello es así, porque, según lo expresó el alto tribunal, la imputación de las actuaciones de los funcionarios o empleados a la Administración se explica a través de la teoría del órgano ${ }^{22}$.

Consecuentemente, cualquiera sea la posición jerárquica que tenga el agente en la estructura de la Administración, él se identifica con la propia autoridad administrativa.

\section{4) La regulación de la responsabilidad es de competencia nacio- nal y provincial}

Una peculiaridad de nuestro régimen de la responsabilidad estatal regida por el derecho público es su carácter local y nacional ${ }^{23}$. En efecto, como consecuencia del régimen federal adoptado por la Constitución Nacional (art. 1 de la Const. Nac.), en cuyo mérito las provincias conservan todo el poder no delegado a la Nación (art. 121 de la Const. Nac.), el derecho administrativo en nuestro país es de naturaleza local.

Precisamente, uno de aquellos poderes reservados y no delegados por las provincias a la Nación es el relativo a la legislación en materia administrativa, pues según el art, 122 de la ley fundamental, las pro-

1993-E, p.912; Cassagne, "Derecho Administrativo", cit. t. I, p. 515; ComadirA, Julio R., Derecho Administrativo. Acto administrativo. Procedimiento administrativo. Otros estudios, $2^{\mathrm{a}}$ ed. act. $y$ ampl. Bs. As., 2003, p. 377 y ss.). Este criterio ha sido receptado, a través de numerosas normas dictadas partir del año 2000, en lo supuestos de revocación de contratos administrativos por razones de oportunidad, mérito o conveniencia (art. 96 del decreto 436/2000; art.12 del decreto 1023/2001; art. 26 Ley 25.344, art. 11 Ley 25.453).

19 Fallos: 169:111; 182:5, 259:261; 270:404; 278:224; 288:362, entre otros muchos.

20 Fallos: $306: 2030$ y en ED t. 114 , p. 215 y ss con nota de CASSAGNE, Juan Carlos, La responsabilidad extracontractual del Estado en la jurisprudencia de la Corte.

21 BielsA, Rafael, Responsabilidad del Estado como poder administrador, JA t. 43, p. 416; Marienhoff, ob. cit., t. IV, p. 715.

22 Ver: PERrino, Pablo E., La responsabilidad de la Administración por su actividad ilícita. Responsabilidad por falta de servicio, ED, t. 185, p. 781.

23 Ver: Gambier, Beltrán y Perrino, Pablo E., ¿Pueden las provincias dictar normas en materia de responsabilidad del Estado?, J.A. 1996-IV, p. 793. 
vincias, por no haber delegado el respectivo poder, se dan sus propias instituciones locales y se rigen por ellas.

En consecuencia las legislaturas provinciales y el Congreso de la Nación, cada uno en su órbita, están facultados para dictar leyes sobre la cuestión bajo examen.

En cambio, al encontrarse regida la responsabilidad de la Administración por actuación en el campo del derecho civil o mercantil por las mismas disposiciones del Código Civil aplicables a las personas privadas, únicamente el Congreso de la Nación es el órgano facultado para su regulación a tenor de lo establecido en el art. 75 , inc. 12 del texto constitucional.

\section{5) Requisitos para que surja el deber de responder del Estado}

En general, la doctrina ${ }^{24}$ y la jurisprudencia de la Corte Suprema de Justicia de la Nación ${ }^{25}$ coinciden en señalar que los presupuestos para que se torne viable la responsabilidad estatal son cuatro: a- la existencia de un daño cierto, real, no hipotético, evaluable en dinero y subsistente; b- posibilidad de imputar jurídicamente los daños a órganos que integren la estructura del Estado, bien sea en su condición de autoridad, empleado en régimen administrativo o laboral, contrato o que realice una gestión de facto; c- el nexo causal adecuado entre el daño y la conducta estatal por acción u omisión ${ }^{26}$ y d- la existencia de un factor de atribución ${ }^{27}$. Este último elemento concierne al fundamento inmediato que se toma en consideración para atribuir jurídicamente la obligación de indemnizar el daño causado ${ }^{28}$. Los más importantes y de carácter genérico que dan lugar al deber de reparar estatal son tres:

a. La falta de servicio, la cual se configura por el funcionamiento anormal, defectuoso o incorrecto de la Administración Pública y se puede producir tanto por acción como por omisión, por actos de alcance individual o general, como por operaciones materiales

24 Cassagne, ob. cit. t. I, p. 555 y ss. y Mertehikian, ob. cit., p. 103 y ss.

25 Fallos: $315: 2865 ; 320: 266 ; 321: 1776$ y 2144 , entre otros.

26 CASSAgne, ob. cit. t. I, p. 555 y ss; y Perrino, La responsabilidad de la administración por su actividad ilícita..., cit.

27 PerRINo, Pablo E., Los factores de atribución de la responsabilidad extracontractual del Estado por su actividad ilícita, obra colectiva Responsabilidad del Estado y del funcionario público, Ciencias de la Administración, Buenos Aires, 2001, p. 59 y ss.

28 VÁzquez Ferreyra, ob. cit. p.193 y Companucci De Caso, Rubén H., Fundamentos de la responsabilidad Civil: culpa y riesgo, en la obra colectiva Derecho de Daños, La Rocca, Bs. As., 1989 , p. 57. 
de los agentes estatales, y se sustenta en el art. 1112 del Código Civil $^{29}$.

b. El riesgo creado, receptado en el art. $1113,2^{\mathrm{a}}$ parte, $2^{\circ}$ párrafo del Código Civil, cuya aplicación en el derecho administrativo, por los motivos que más adelante exponemos, debe efectuarse por vía analógica y no en forma directa.

c. La existencia de un sacrificio o daño especial ${ }^{30}$, derivado de la quiebra del principio constitucional de igualdad ante las cargas públicas (art. 16 de la Const. Nac.), y que el afectado no está obligado a soportar ${ }^{31}$.

\section{LA RESPONSABILIDAD POR RIESGO}

\section{1) Origen y fundamentos}

La teoría del riesgo, de origen francés, desarrollada por el Consejo de Estado a principios del siglo XX movido por el deseo de proteger a las víctimas del daño ${ }^{32}$, fue receptada en nuestro derecho a través de la reforma de la Ley 17.711 del año 1968 en el art. $1113,2^{\circ}$ párrafo, $2^{a}$ parte del Código Civil, mediante un texto que ha dado lugar a distintas interpretaciones ${ }^{33}$.

29 Perrino, Pablo E., La responsabilidad de la administración por su actividad ilícita. Responsabilidad por falta de servicio, ED, 185-781.

30 La teoría del sacrificio especial constituye una construcción desarrollada por la Corte Suprema de Justicia de la Nación (Fallos: 180:107; 310:943; 316:397; 319:2658, entre otros). Así, en el caso "S.A. Corporación Inversora Los Pinos c/Municipalidad de la Ciudad de Bs. As.", registrado en Fallos: 293:617, el alto tribunal fundamentó la responsabilidad lícita del Estado con estas palabras: "... el sacrificio impuesto en forma particular a la actora en beneficio de la comunidad, no es propio que sea soportado únicamente por aquella; lo contrario sería en desmedro del principio de igualdad ante la ley y las cargas públicas consagrado en el art. 16 de la Constitución Nacional"; ver: Bianchi, Alberto B., Responsabilidad del Estado por su actividad legislativa, Abaco, Bs. As., 1999, p. 55 y ss.).

31 El recaudo concerniente a la ausencia del afectado del deber jurídico de soportar el daño para que proceda la responsabilidad lícita del Estado fue exigido por la Corte Suprema de Justicia de la Nación en el caso "Columbia SA. de Ahorro y Préstamo para la Vivienda c/ Banco Central de la República Argentina", decidido el 19/5/92 (Fallos:315: 1026; ver: Coviello, Pedro J.J., El caso Columbia: nuevas precisiones de la Corte sobre la responsabilidad por actos estatales normativos, Rev. de Der. Adm. n 9/11, p.139 y ss.). Cassagne, considera que, en rigor, en estos casos el factor de atribución es la ausencia del deber de soportar el daño. (Reflexiones sobre los factores de atribución en la responsabilidad del Estado por la actividad de la Administración, LL, supl. diario del 28/7/05).

32 Sempé, Francoise, La responsabilidad extracontractual de la Administración en Francia, cit. p. 985.

33 Ver: Pizarro, Ramón D., Responsabilidad por el riesgo o vicio de la cosa Editorial Universidad, Buenos Aires, 1983 , p. 310 y ss. 
Este factor de atribución de carácter objetivo se ha sustentado en tres criterios diferentes ${ }^{34}$ :

a) Teoría del riesgo creado: considera que quien es dueño o guardián de cosas riesgosas, o realiza actividades que por su naturaleza o forma en que se la realiza, genera riesgos potenciales a terceros, debe responder por los daños que de ellos derivan. Según este criterio debe responder quien introduce en la comunidad alguna situación que potencia o multiplica la posibilidad de producir daños ${ }^{35}$.

b) Teoría del riesgo beneficio: este criterio acota la responsabilidad a los supuestos de $\mathrm{n}^{36}$ para el dueño o guardián de la cosa.

c) Teoría del acto anormal: limita la doctrina del riesgo creado ya que postula que quien ocasiona un riesgo solo responde por sus consecuencias extraordinarias, resultantes de una actividad fuera de lo normal ${ }^{37}$.

La mayoría de nuestra doctrina y numerosos pronunciamientos judiciales entienden que el art. $1113,2^{\circ}$ párrafo, $2^{\mathrm{a}}$ parte del Código Civil receptó la doctrina del riesgo creado $^{38}$, ya que en él se hace responsable al sujeto que ha introducido en la sociedad la fuente de peligro, sin importar si obró en forma dolosa o culposa.

\section{2) ¿Quienes responden?}

De acuerdo al art. $1113,2^{\circ}$ párrafo de la legislación Civil los sujetos responsables son el dueño o propietario de la cosa y su guardián.

34 Pizarro, Código Civil y normas complementarias. Análisis doctrinario y jurisprudencial, T. 3-A, dirigido por Bueres, Alberto J. y coordinado por Highton, Elena, Hammurabi, Buenos Aires, 1999, ps. 498/499

35 Zavala de González, Matilde, Resarcimiento de daños, T. 4, Hammurabi, Buenos Aires, 1999, ps. 398/399.

36 Zavala de GonZÁlez, op. antes cit., T. 4, ps. 400/403.

37 Pizarro, Código Civil y normas complementarias. Análisis..., cit., T. $3^{\text {a }}$, p. 499.

38 Mosset Iturraspe, Jorge, Responsabilidad por daños, T. I, Ediar, Buenos Aires, 1971, nº 53, p. 128 y ss.; Bustamante Alsina, Jorge, Teoría general de la responsabilidad civil, $3^{\circ}$ ed., Abeledo-Perrot, Buenos Aires, 1980, n 1020-1031, ps. 354-357; BordA, Guillermo A., La reforma de 1968 al Código Civil, Perrot, Buenos Aires, 1971, n 138, ps. 213 y 214; GARrido, Roque F., El art. 1113 y la inversión de la carga de la prueba, JA, doctrina, 1971, p. 265 y ss.; Alterini, Acilio A., Responsabilidad civil, Abeledo Perrot, Buenos Aires, $1974, \mathrm{n}^{\circ} 119$ a 122, p. 106 y ss.; PIZARRo, Ramón D, Código Civil y normas complementarias. Análisis..., cit., p. 543; GALDós, Jorge Mario, ¿El riesgo creado suprimió el régimen de la culpa del Código Civil de Vélez Sarfield?. T. II, Academia Nacional de Derecho y Ciencias Sociales de Córdoba, Separata de homenaje a Dalmacio Vélez Sarsfield, Córdoba, 2000, p. 427 y ss. 
Si bien la noción de dueño no presenta dificultades, ya que es tal el sujeto titular del derecho real de dominio sobre la cosa, no acontece lo mismo con el concepto de guardián, sobre el cual la doctrina ha elaborado numerosos criterios ${ }^{39}$.

Más allá de ello, lo cierto es que el citado precepto de la legislación civil contiene dos pautas de suma relevancia para delimitar la noción de guardián de la cosa. Así, en su primer párrafo se dispone que es responsable quien "se sirve" de la cosa (guarda-provecho) y quien la "tiene a su cuidado" (guarda-control) ${ }^{40}$.

\section{3) Naturaleza de la obligación de resarcir}

En cuanto a la naturaleza de la obligación de resarcir que pesa sobre los responsables, la doctrina mayoritaria afirma que es de carácter concurrente $^{41}$, lo cual implica que surgen frente a la víctima dos relaciones jurídicas obligatorias y diferentes, si bien conexas y vinculadas: la del dueño y la del guardián. El damnificado, por ende, tiene la posibilidad de accionar contra ambos o elegir uno de ellos.

\section{4) Eximentes de responsabilidad}

Según lo dispone el art. $1113,2^{\circ}$ y $3^{\circ}$ párraf. del Código Civil, el dueño o guardián de la cosa solo se eximen de responsabilidad si acreditan la intervención de una causa ajena al riesgo o vicio de la cosa, tales como (i) el hecho de la propia víctima, (ii) de un tercero por quien no deben responder ( $2^{\circ}$ párrafo del precepto citado) o (iii) cuando la cosa fue usada contra la voluntad del dueño o guardián (último párrafo del artículo de referencia).

A pesar de que no se lo menciona en el art. 1113 del Código Civil, se entiende que el caso fortuito, cuando es externo a la cosa productora

39 Ellos son los siguientes: a) guarda material, b) guarda jurídica, c) guarda intelectual o poder de mando, d) guarda provecho, y d) doctrinas mixtas que combinan elementos de las anteriores (ver: Pizarro, Responsabilidad civil por el riesgo o vicio de la cosa cit., p. 379 y ss.; Kemelmajer de Carlucci, Aída, Código Civil y leyes complementarias, comentado, anotado y concordado, T. 5, dirigido por Belluscio Augusto C. y coordinado por ZANNONI, Eduardo A., Astrea, Buenos Aires, 1984, ps. 470 y ss.).

40 Ver Zabala de González, ob. cit., T. 4, p. 597 y Pizarro, Código Civil y normas complementarias..., cit, t. $3^{\mathrm{a}}$, ps. 526/528.

41 Mosset Iturraspe, "Responsabilidad por culpa y responsabilidad por riego creado", en Estudios sobre responsabilidad por daños, T. I, 1980, p. 66; LlambÍAs, Tratado de Derecho civil. Obligaciones, $3^{\circ}$ ed., T. IV-A, p. 560, $\mathrm{n}^{\circ}$ 2609; Trigo Represas, Félix A., en Cazeaux - Trigo Represas, Derecho de las obligaciones, T. IV, $3^{\circ}$ ed,, 1994, p. 705; Borda, Tratado de derecho Civil. Obligaciones, T. II, $4^{\circ}$ ed., 1976, ps. 344-345, n 1470, d); Pizarro, Código Civil y normas complementarias..., cit, c. $3^{\text {a }}$, p. 539. 
del daño, también constituye una causal de exención de la responsabilidad, pues en tal caso se produce la interrupción del nexo causal (arts. 513 y 514 del Código Civil $)^{42}$.

\section{Aplicación judicial del factor Riesgo a la Responsabilidad ESTATAL}

Explicados los lineamientos de la responsabilidad por riesgo creado receptada en nuestra legislación civil y previo a efectuar algunas consideraciones acerca de la aplicación de la teoría del riesgo al ámbito estatal, efectuaremos una pequeña reseña de casos en los que se condenó al Estado con arreglo a dicho factor de atribución ${ }^{43}$.

\section{1) Daños provocados por la caída de árboles}

Son muy numerosos los casos en los que se ha condenado al Estado ${ }^{44}$ por los daños ocasionados por la caída de árboles en la vía pública, por entenderse que él es su dueño o guardián, en los términos del $2^{\circ}$ párrafo del art, 1113 del Código Civil, y tiene a su cargo el cuidado, mantenimiento, conservación y reparación ${ }^{45}$.

42 Trigo Represas, Félix A. y Companucci De Caso, Rubén, Responsabilidad civil por accidentes de automotores, T. 2-B, Hammurabi, Buenos Aires, 1987, p. 358 y ss.

43. En más de una ocasión la Corte Suprema de Justicia ha resuelto que el uso y goce de los bienes del dominio público por parte de los particulares importa para el Estado (considerando lato sensu) la obligación de colocarlos en condiciones de ser utilizados sin riesgos. (Causa "Bullorini, Jorge Alberto y otro c/ Córdoba, Provincia de", sent. del 1/3/94, Fallos: 317:144).

44 Respecto a la condición del Estado de propietario de los árboles que se hallan en la vía pública se ha resuelto, con cita de Miguel S. Marienhoff, que al estar allí emplazados representan un accesorio del dominio público. Con base en ello se ha afirmado que es la municipalidad la que debe tomar las precauciones que resulten necesarias para salvaguardar la integridad de las personas y cosas que podrían resultar dañadas por bienes que pertenecen o son accesorios del dominio público (CNCiv., Sala $\mathrm{H}$, causa "Marles, Benito c. Gobierno de la Ciudad de Buenos Aires", sent. del 9/5/2000, LL 2001-B, 425).

45 CNCiv. Sala F, causa "Carusso de Reboredo, Inés y otro c. Municipalidad de la Ciudad de Buenos Aires", sent. del 24/7/1979, ED, 85-262, Sala A, causa "Pérez, Danilo D. C. Municipalidad de la Capital", sent. del 5/7/1985, LL 1985-D- 278; Sala M, causa "Hamicha, Blanca R. c. Municipalidad de Buenos Aires", sent. del 14/9/1998, LL 1999-C- 61, y C.Fed. San Martín, causa "Báez, Gabriel y otro c/Municipalidad de San Isidro y otra", sent. del 10/11/98, JA 1999-II, p. 192, con nota de Mosset ItUrRaspe, Jorge, Sensibilidad frente a las "villas": deberes municipales con los asentamientos precarios, p. 203. 


\section{2) Daños ocasionados por el mal estado de aceras ${ }^{46}$, calles y rutas}

Se ha condenado al Estado por perjuicios derivados de baches, pozos $^{47}$, excavaciones ${ }^{48}$, levantamiento pronunciado de la carpeta asfáltica ${ }^{49}$, montículos que afectan la circulación sin estar debidamente señalizados ${ }^{50}$, adoquines sueltos en la calzada ${ }^{51}$, obstáculos en la vía pública $^{52}$, tapas de desagües pluviales y alcantarillas faltantes o en mal

46 Al respecto la $\mathrm{CNCiv}$, Sala F sentenció que, si bien es cierto que la municipalidad es la propietaria de la acera, siendo estas de dominio público del Estado Municipal y que las distintas municipalidades tienen la obligación de construirlas y conservarlas en buen estado, también es cierto que el municipio ha delegado la responsabilidad primaria y principal de la construcción, mantenimiento y conservación de las veredas a los propietarios frentistas. No obstante esta delegación, la municipalidad guarda para sí el ejercicio del poder de policía que le impone el deber de asegurar que las veredas tengan una mínima y razonable conformación, para evitar que la deficiente conservación de la cosa, se transforme en fuente de daños para terceros. Por tal razón, la responsabilidad que pueda atribuirse a un frentista no releva la correspondiente al Gobierno de la Ciudad de Buenos Aires (Causa Pescio, Lucía María c. Municipalidad de la Ciudad de Buenos Aires s/ daños y perjuicios", sent. del 30/4/2001, ED, 194-588).

47 La Cam. Nac. Civ., Sala D, condenó al Gobierno de la Ciudad a indemnizar el daño sufrido por el actor al caer en la acera debido a la presencia de un pozo -en el caso, causado por el derrumbe de un árbol- que no había sido reparado, pues, entendió, que tal daño era el resultado de actos derivados de la puesta en la vida social de un riesgo suplementario a los ya existentes, lo que contribuyó a repotenciar la eventualidad dañosa Causa "Gallino, Filomena T. c/ G.C.B.A", sent. del 5/9/01, LL 2002 C, 52-103581).

48 En tal sentido se ha resuelto que una excavación abierta en una calle, carente de las elementales medidas de seguridad, constituye una cosa riesgosa o peligrosa en los términos del art. 1113 CC. Por tanto, los daños originados por el aludido riesgo deben ser reparados por el dueño, la municipalidad, el titular del dominio público de las calles y por el guardián de la obra (CCiv. y Com. Morón, sala II, 26/02/1987, Neves Pereira, Eugenio c. Municipalidad de Morón y otra", JA, 1988-I, p. 72, síntesis).

49 Causa "Bullorini, Jorge Alberto y otro c/ Córdoba, Provincia de", sent. del 1/3/94, Fallos: 317: 144 .

50 La CCiv y Com de Mar del Plata ha fallado que si de la prueba agregada se concluye que existía una apertura del pavimento y montículo de tierra en una avenida al momento del accidente, no existiendo valla ni señalización alguna, el municipio debe responder por ser dueño de la cosa pública, en el caso la vía pública. Por dueño debe entenderse al titular del derecho real de dominio definitivo en el art. 2506 del CCI. También la Empresa contratada y el contratista son responsables por ser guardianes de la cosa en los términos del art. 1113 2da. parte del Código Civil. (Causa: "Perkins Arnaldo c/ Rossi Obsulio s/ Daños y perjuicios", sent. del 9/1097; ver CCiv. y Com de Azul, causa "Gómez, Liliana H. c. Municipalidad de Benito Juárez y otro", sent. del 1/07/1997, LLBA 1997, 1370 y CCiv y Com de Familia y del Trabajo de Río Tercero, causa "Sandrone, Dolly o Doli, Margarita c. Municipalidad de Hernando y otros", sent. del 15/10/1998,LL 1999-C, 740 y en LLC 1998, 1498).

51 "Es responsable la Municipalidad por las lesiones sufridas por un peatón como consecuencia de la mordida de un adoquín suelto por parte de un vehículo que hizo que este saliera proyectado contra el peatón, ya que está a cargo de la Comuna el mantenimiento de la calzada" (CNCiv. y Com. Fed., sala II, causa "Martínez González, Eudaldo c. Municipalidad de la Ciudad de Buenos Aires", sent. del 14/9/84, ED, 113-134).

52 El Gobierno de la Ciudad de Buenos Aires fue condenado por los daños producidos por un "lomo de burro" no autorizado y sin señalizar y que ocasionó lesiones a un motociclista, 
estado $^{53}$, aperturas de zanjas efectuadas por empresas concesionarias de servicios públicos 54 , etc.

\section{3) Trampolines instalados por un municipio en una playa que ocasionan daños a un bañista}

La Corte nacional condenó a la Municipalidad de Puerto Madryn y a la Provincia de Chubut por los daños sufridos por un nadador al saltar de un trampolín instalado en la playa por el municipio demandado. El tribunal entendió que si bien el trampolín era una cosa inerte, por las condiciones donde fue instalado cabía considerarlo como cosa riesgosa y, aun viciosa, en relación con el uso al cual estaba destinado. La Corte hizo responsable de los perjuicios al municipio porque no obstante ejercer el poder de policía sobre la playa, que le había sido delegado por una ley local, no había adoptado medidas de seguridad destinadas

toda vez que está a su cargo el control y conservación de las calles de la ciudad, evitando que la deficiente conservación o la existencia de vallas u obstáculos autorizados o no, se transformen en una fuente de daños (CNCiv., Sala F, causa "B., F. O. y otro c. GCBA", sent. del 4/7/2001, LL 2001-F, 566).

53 Así se ha resuelto que la rejilla metálica que forma parte de las instalaciones de una empresa distribuidora de energía eléctrica como respiradero de un centro de transformación subterráneo ubicada en la vereda, no es de por sí generadora de riesgo, sino que adquiere el carácter de cosa peligrosa o viciosa por la forma en que ha sido construido, esto es por encontrarse elevada unos centímetros del nivel de la vereda, perjudicando de ese modo el normal tránsito de las personas por el lugar. Si la cosa cuyo riesgo o vicio produjo el daño se encontraba en la vía pública -en el caso, lesiones al tropezar con una rejilla metálica- y en tanto las aceras forman parte del Estado y se encuentran bajo la guarda de la Municipalidad, es este el factor de imputación jurídica para que aquella responda por el perjuicio ocasionado en la órbita del art. 1113 del Cód. Civil, pues era su deber mantener en condiciones la vereda para evitar perjuicios a terceros, tanto dentro de las funciones de policía que le atañen como por ser la vía pública parte del dominio público del Estado (Cam. Nac. Civ., Sala H, causa "Moltedo de Dickson, Nelly M. c/ Empresa Distribuidora Sur S.A. y otro", sent. del 25/4/01, LL 2001 D, 692-102428; conf. Sala I, causa "Cabral de Sava Librada c/OSN", LL 1997-B, p. 797).

Al respecto, la CNCiv., Sala G, expresó que caminar por la vereda, aunque sea por un lugar conocido, no implica aceptar un altísimo riesgo de dañosidad o ni puede considerarse temeraria la conducta que provoca serias lesiones físicas y psíquicas. Por lo tanto, no es legítimo presumir que la víctima haya querido sufrir el daño, máxime al recordar que la falta a la que alude el art. 1111 CC. no es, en principio, sinónimo de culpa, más bien de infracción y no hay vestigio de esta en el hecho de caminar por la vía pública. La aceptación del riesgo que entraña caminar por una vereda atravesando una zanja por una precaria cubierta no puede generar la exención de responsabilidad de quien generó el riesgo al dejar la obra sin protección suficiente. El Gobierno de la Ciudad de Buenos Aires no puede autorizar la apertura de zanjas y desentenderse totalmente de los daños que se produzcan, so pretexto de que la responsabilidad recae sobre la empresa que realiza el trabajo. La cosa no está independizada del control absoluto del titular del dominio público (arts. 2339 y 2340, inc. 7 CC.), toda vez que este tiene el deber de controlar que las obras en la vía pública se realicen en condiciones tales que las personas puedan transitar por ella sin peligro. (Causa "Argibay, Haydée v. Telecom Argentina S.A. y orro", sent, del 22/9/1997, LL 1998-II, 175). 
a prevenir a las usuarios sobre las peligrosas condiciones de emplazamiento de los trampolines y a la provincia por su condición de titular del dominio de la playa (art.2339 y 2340, inc. 4 del Código Civil), lo cual implica el de las cosas accesorias instaladas en ella (arts. 2315, 2328 y 2571 del código citado $)^{55}$.

4) Perjuicios producidos a raíz de la caída de parte de la mampostería de un monumento público y la demolición de un inmueble

La Sala G de la Cámara Nacional de Apelaciones en lo Civil ${ }^{56}$ condenó al Estado Nacional en su condición de guardador de la estructura y conservación de la Catedral de Buenos Aires por los daños ocasionados a un transeunte por la caída de parte de la mampostería del edificio ${ }^{57}$. A su vez, la Sala $C$ de la misma cámara condenó a la ex municipalidad de Buenos Aires por los daños sufridos por un automóvil a raíz de la demolición de un inmueble de su propiedad para la construcción de una autopista, como así también y en forma solidaria, a la empresa contratista encargada de las demoliciones ${ }^{58}$.

\section{5) Perjuicios ocasionados por el mal funcionamiento de ascen- sores en edificios públicos}

En más de una ocasión se ha condenado al Estado con basamento en el art. $1113,2^{\circ}$ párrafo, $2^{a}$ parte, del Código Civil, por los daños ocasionados por el mal funcionamiento de ascensores en edificios públicos 59 .

55 Fallos: 315:2834 y en JA 1994-II, p. 262, con nota de Lorenzetti, Ricardo L., El riesgo y el daño a la persona en la Corte Suprema, p. 269.

56 Causa "Pérez Garrido de Sánchez Lucca, María I. c/Arzobispado de Buenos Aires", ED, $168-96$.

57 Es interesante destacar que en la causa no se condenó al Arzobispado de Buenos Aires porque se entendió que se había operado el desplazamiento de la guarda y, por tanto de la responsabilidad, en virtud de la Ley 12.665 que confiere al gobierno federal la conservación y custodia de los Monumentos, Museos y Paseos o Lugares Históricos, entre los que se encuentra el nombrado edificio (art, 4 de la ley citada y decreto reglamentario $120412 / 42$ ).

58 Causa "Bloomfield, J. A. C. Autopistas Urbanas S.A. y otros", sent, del 26/4/1983, ED, 104-747.

59 Cam. Nac. Civ, sala C, 11/5/1993, causa "Muratona, Lidia E. v. Municip, de Buenos Aires", JA 1994-IV-síntesis; C. Nac. Civ. y Com. Fed., sala 3", 2/10/2002, - "Moreno, Ilda Catalina R. y. Hospital General de Infecciones F. J. Muniz y otros s/daños y perjuicios"; C. Nac. Civ. y Com. Fed. Sala II, causa "D. de P., M. S. y otros c. Banco Hipotecario Nacional y otros", sent. del 20/3/1997, LL, 1998-E, 758 y DJ 1999-2, 361. 


\section{6) Daños provocados por explosivos}

Se ha considerado responsable a la Dirección General de Fabricaciones Militares, en forma concurrente con el Ejército Nacional, por su condición de fabricante de una granada que explotó durante la realización de ejercicios militares ocasionándole daños al actor, cadete del Colegio Militar, con fundamento en el factor de atribución objetivo encuadrado en el art. 1113 Código Civil que consagra el deber de responder por el vicio de las cosas y por las circunstancias de haber creado un riesgo al lanzar al mercado aquel producto defectuoso ${ }^{60}$.

\section{7) Daños provocados por el uso de armas de fuego por parte de policías o integrantes de fuerzas de seguridad, aún en franco de servicio}

Los pronunciamientos de la Corte Suprema de Justicia de la Nación en lo que concierne a la responsabilidad estatal por perjuicios ocasionados por el uso de armas de fuego por parte de policías o integrantes de fuerzas de seguridad ${ }^{61}$ no es uniforme, ya que en algunas ocasiones -de disímiles características- se la ha sustentado en el art. 1112 del Código Civil ${ }^{62}$, y en otras (en la mayoría de los casos) en el art. $1113,2^{\circ}$ párrafo, $2^{a}$ parte del Código Civil, ya sea por el carácter riesgoso del arma suministrada por la repartición ${ }^{63}$ como en el de la actividad desarrollada ${ }^{64}$.

60 Cam. Civ. y Com. Fed, Sala III, causa "Pliauzer, Juan P. c/ Estado Nacional", sent. del 17/8/00, JA 2001 I, 275.

61 En algún supuesto, debido a las particularidades de la causa se ha eximido al Estado de responsabilidad. Así por ejemplo la Corte Suprema de Justicia de la nación rechazó la demanda de daños y perjuicios causados por un disparo de arma de fuego a quien, usando un arma intentó robar, porque entendió que el agente policial interviniente adoptó las diligencias que pueden considerarse razonablemente exigibles en atención a las circunstancias de tiempo y lugar en que se produjo el suceso (causa G. 251. XXIII, "Gómez, Javier Horacio cl Quiroz, Alfredo y Estado Nacional (Policía Federal)", sent. del 30/6/98, Fallos: 321:1776).

62 Así, por ejemplo en los precedentes: "Velasco Angulo, Isaac c/ Buenos Aires, Provincia de", sent. del 15/9/87 (Fallos: 310: 1826); "Lozano Gómez, Juan Carlos c/ Buenos Aires, Prov. de", sent. del 12/5/92 (Fallos: 315:968 y en la Rev. de der. Adm. $N^{\circ} 12 / 13$, p. 151, con nota de González Arzac, Rafael M., Responsabilidad del Estado por daños con armas disparadas en cumplimiento regular de la función policial, p.133 y ss.); Rebesco, Luis Mario c/ Policía Federal Argentina (Estado Nacional - Ministerio del Interior)", sent. del 21/3/1995 (Fallos: 318:385), en los cuales a pesar de que el comportamiento policial dañoso fue considerado lícito, se invocó el art. 1112 de la legislación civil que es el sustento normativo de la falta de servicio. También se citó este precepto por en pleitos en los cuales el accionar policial fue reputado irregular. Así por ejemplo en la causa "Morales, María Beatriz c/Prov. de Buenos Aires" (Fallos:315:1902).

63 Cam. $1^{\circ}$ de Apel. Civ. y Com. La Plata, Sala 2, causa "Heine, José Luis c/Gob. Prov. de Buenos Aires", sent. del 24/2/91, Base de datos JUBA.

64 CSJN causa "Balbuena, Blanca Gladys c/Prov. de Buenos Aires", sent. del 5/7/94, Fa1los: 317: 727; causa "Furnier, Patricia M, c/Prov. de Bs.As.", sent. del 27/9/94, Fallos: 
La tendencia jurisprudencial mayoritaria postula incluso la responsabilidad estatal cuando el agente actúe en franco de servicio ${ }^{65}$, en virtud de la obligación que tienen de actuar en cualquier momento a fin de prevenir la comisión de delitos y, en consecuencia, a portar el arma reglamentaria en todo momento.

Con base en dicha circunstancia, la Corte Suprema de Justicia de la Nación ha expresado en numerosas ocasiones que resulta lógico admitir que los perjuicios que de ello deriven sean soportados por la comunidad en general y no solo por los damnificados, pues si la protección pública genera riesgos, lo más justo es que esos riesgos sean soportados por todos los que se benefician con ella.

Asimismo, ha sostenido que la función de policía de seguridad exige la preparación técnica y síquica adecuada de sus integrantes para preservar racionalmente la integridad de todos los miembros de la sociedad y de sus bienes ${ }^{66}$.

Cabe destacar que en algunos casos en los que el obrar del agente estaba desvinculado de la función y en franco de servicio se ha admitido la exoneración de responsabilidad del Estado ${ }^{67}$ afirmándose que no basta para condenarlo su condición de titular del arma empleada, pues según lo dispone el art. $1113,2^{a}$ parte, el dueño de la cosa puede exonerarse acreditando su falta de culpa ${ }^{68}$.

317:1006; causa "Scamarcia, Mabel y otro c/Prov. de Buenos Aires y otro", sent. del 12/9/95, causa I. 117 XXV, Izaurralde, Roque Rafael c/Buenos Aires, Provincia de y otro s/daños y perjuicios", sent, del 31/8/99, Fallos: 322:2002 (en este último pronunciamiento si bien se adujo, como en las decisiones anteriores, que la actividad policial era de índole riesgosa, el tribunal invocó el art, 1112 y no el art. 1113 del Código Civil); ver también: CCiv. y Com. La Plata 2a, Sala II, causa "Montorro, Salvador y otro c. Miranda, Oscar R. y otro", LI. 1985-C, p. 319, con nota de Ghersi, Carlos Alberto, Responsabilidad del Estado por actos dañosos de sus dependientes (artículo 1113 del Código Civil).

65 Ver fallos citados en la nota anterior.

66 Ver fallos citados en la nota 43.

67 Conf. MATA, Ismael, Responsabilidad del Estado por ejercicio del poder policía, obra colectiva Responsabilidad del Estado y del funcionario público, Ciencias de la Administración, Buenos Aires, 2001, p. 180.

68. En este caso el disparo del arma que culminó con la muerte de la víctima se había producido por un integrante de la Prefectura Naval en franco de servicio a raíz de una discusión familiar (CNFed. Civ. y Com., Sala III, causa "Castellano, Carlos R. Y otro c/Nievas, Jorge L. y otro", LL 1994-A, p. 411 y CSJN causa "Izaurralde," antes cit., disidencia del juez Vázquez, y CNFed. Civ. y Com., Sala III, causa "Civilotti, Julio O. y otro c/ Vega, Juan M. y otro", sent. del 15/4/97, LL 1998-C, p. 201, con nota de Bustamante Alsina, Jorge, ¿La responsabilidad extracontractual del Estado es indirecta y subjetiva o directa y objetiva?". En este último pronunciamiento si bien la alzada descartó como en el caso "Castellano" la responsabilidad estatal por la sola condición de ser el titular del arma homicida (art. $1113,2^{\circ}$ párrafo del Código Civil) y por la existencia de culpa in eligendo o in vigilando, concluyó que en el caso mediaba una responsabilidad indirecta y tangencial responsabilidad de la Prefectura en cuanto habría una dosis de causalidad en el hecho de obligar a portar el arma reglamentaria en forma permanente y fuera del ámbito específico de su función a personas que -tal vez-aún no poseen un grado de maduración suficiente para ejercer semejante responsabilidad y asumir sus consecuencias. 
8) Perjuicios ocasionados a raíz de la muerte de un menor producida por la utilización de un muelle en mal estado

La Sala $1^{\text {a }}$ de la Cámara Civil y Comercial II de La Plata condenó a la Provincia de Buenos Aires y a la Municipalidad de Chascomús por la muerte de dos personas (padre e hijo) ocasionada por la utilización de un muelle en mal estado construido sobre el río Salado.

La alzada consideró que el muelle, cuyo constructor se ignoraba, ubicado sobre un campo privado, por el hecho de estar adherido físicamente al cauce de un bien del dominio público, como era el río Salado, tenía esa misma condición y generaba la responsabilidad de la provincia en los términos del art. $1113,2^{\mathrm{a}}$ parte, $2^{\circ}$ párrafo, del Código Civil ${ }^{69}$.

A su vez, el municipio fue condenado por la omisión en el ejercicio de los poderes de vigilancia, control y conservación del lugar que tenía a su cargo.

\section{9) Daños producidos por la circulación de automotores oficiales ${ }^{70}$}

En múltiples precedentes la Corte Suprema de la Nación ha resuelto que en el supuesto de accidentes en los que intervienen dos o más automotores la sola circunstancia de la existencia de un riesgo recíproco no excluye la aplicación de lo dispuesto en el art. 1113, párrafo $2^{\circ}$ del Código Civil, que regula lo atinente a la responsabilidad por el hecho de las cosas y, de tal suerte, se crean presunciones de causalidad concurrentes como las que pesan sobre el dueño o guardián, quienes deben afrontar los daños causados a otros salvo que prueben la existencia de factores eximentes ${ }^{71}$.

\section{0) Red de volley colocada peligrosamente}

Se ha condenado a la Provincia de Buenos Aires por los daños sufridos por un alumno de un establecimiento escolar ocasionado por la existencia de una red de volley con un cable de acero que se encontraba colocado en forma peligrosa ya que estaba tenso a la altura de la cabeza de los niños ${ }^{72}$.

69 Causa B.84.358, "Dobronich de Seoane c/Provincia de BS. As. s/daños y perjuicios", sent. del $26 / 6 / 97$.

70 CSJN, causa V., R. E. c. Provincia de Buenos Aires y otro", sent. del 10/4/2003, LL 2003-E, 416 y en DJ 2003-2, 1109.

71 Causa "Moreno, Francisca N. c/Prov. de Buenos Aires", sent. del 9/3/04, ED, supl. de Der. Adm. del 30/7/04, y sus citas. En este caso el vehículo del actor fue embestido por un móvil policial que circulaba a gran velocidad con las balizas y sirenas encendidas.

72 Así se expresó que pesa sobre el establecimiento escolar un deber de seguridad, el que hace necesario un control estricto por parte del docente en los lugares en que están los 


\section{Algunas reflexiones aCerca de la aplicación de la teoría DEL RIESGO A LA RESPONSABILIDAD ESTATAL}

Después de haber examinado los rasgos esenciales del régimen de la responsabilidad del Estado, como la regulación positiva del factor de atribución riesgo y el casuismo jurisprudencial, cabe ahora efectuar algunas reflexiones acerca de la aplicación de la teoría del riesgo al campo estatal.

Comenzaremos con algunas consideraciones que son comunes a los supuestos en los que el perjuicio es atribuible a un sujeto privado, para después realizar algunos comentarios respecto de la forma en que se aplica el art. $1113,2^{\circ}$ párrafo en el caso de daños ocasionados por cosas de titularidad o guarda estatal.

\section{1) Reflexiones comunes a los daños originados por sujetos pú- blicos o privado. Amplio alcance del art. $1113,2^{\circ}$ párrafo, $2^{a}$ parte, del Código Civil}

La primer observación que efectuamos se vincula con la generosa y amplia aplicación que se realiza del factor de atribución riesgo creado, cualquiera sea el sujeto (público o privado) autor del daño.

Como hemos señalado anteriormente, un importante sector de la doctrina y la jurisprudencia comparten una conceptualización muy amplia de lo que se debe entender por "riesgo de la cosa"73 que, en rigor, supera la letra del art. $1113,2^{\circ}$ párrafo, $2^{\mathrm{a}}$ parte, del ordenamiento civil, como ocurre, por ejemplo, con las denominadas actividades peligrosas o riesgosas ${ }^{74}$.

niños (aulas, pasillos, baños, etc.) de modo que la presencia del mismo constituya un llamado de atención para quien hiciere algo inoportuno. Al respecto, la existencia de una red de vólley con un cable de acero dejado tenso a la altura de la cabeza de los alumnos cuando estos estaban en recreo constituía un peligro cierto para estos, lo cual exigía que se retirara la red o a lo menos levantar o destensar la banda inferior. Es que tratándose de niños de ocho (8) años, sin responsabilidad legal (art. 921 Cód. Civil) por carencia de discernimiento, no bastaban recomendaciones de "prudencia" o que supieran de la existencia de la red. En consecuencia, acontecido el daño, aun cuando para él hubiere contribuido la distracción de la víctima, frente al riesgo creado ha de responsabilizarse plenamente al establecimiento y su personal docente (art. 902 y 1113 Cód. Civil). (CCiv. y Com. San Nicolás, causa "Rossi José Rufino cl Provincia de Buenos Aires (Dirección de Escuelas) s/ Daños y perjuicios", sent. del 22/3/94, DJBA t.148, p. 53 y en JA 1995- I, p. 253).

73 Ver: GaLdós, Jorge Mario, ¿El riesgo creado suprimió el régimen de la culpa del Código Civil de Vélez Sarsfield?, T. II, Academia Nacional de Derecho y Ciencias Sociales de Córdoba, Córdoba, 2000, p. 428 y ss.

74 Ver: LORENZETTI, Ricardo Luis, Estudio sobre la nueva concepción normativa del riesgo creado en el derecbo argentino, publicado en la obra colectiva Derecho de Daños, T. I, dirigida por Aída Kemelmajer de Carlucci y coordinada por Carlos A. Parellada, Ediciones la Rocca, Buenos Aires, 1993, p. 347 y ss. En el despacho mayoritario elaborado en 
Por otro lado, se entiende casi sin vacilaciones que la cosa productora de riesgo, en los términos del citado precepto de la legislación civil, es aquella que en función de su naturaleza o según su modo de utilización, genera riesgos a terceros ${ }^{75}$, por lo que aun una cosa inerte -la que considerada en sí misma puede no ser peligrosa- en ocasiones, en función de las circunstancias del caso, puede alcanzar ese carácter ${ }^{76}$.

Así, Pizarro ${ }^{77}$ afirma que cuando el art. 1113 hace alusión a los daños por el riesgo de la cosa comprende con amplitud tres categorías:

- daños causados por cosas que son, por su propia naturaleza, riesgosas o peligrosas;

- daños causados por el riesgo de la actividad desarrollada mediante la utilización de una cosa que, no siendo peligrosa o riesgosa por naturaleza, ve potenciada su aptitud para generar daños por la propia conducta del responsable, que multiplica o aumenta la posibilidades de dañosidad.

- daños causados por actividades riesgosas, sin intervención de cosas.

Pero, además, como destaca Galdós ${ }^{78}$ se ha diluido la línea divisoria que efectúa el $2^{\circ}$ párrafo del art. 1113 del Código Civil entre los llamados daños causados con las cosas respecto de los causados por el riesgo o vicio de la cosa, produciéndose una suerte de equiparación de los primeros con los segundos.

Recordemos que la norma citada efectúa una relevante distinción entre dos tipos de responsabilidad derivadas de la intervención de cosas:

a. Daños causados con las cosas $\left(1^{a}\right.$ parte del $2^{\circ}$ párrafo del art. 1113), el cual acontece cuando se provoca un daño por la inter-

las Jornadas Bonaerenses, llevadas a cabo entre el 27 al 29 de octubre de 1994 en la ciudad de Junín, se concluyó que "el art.1113 del código civil comprende las actividades riesgosas aunque no hayan sido urilizadas cosas en la causación del perjuicio". En cambio, en el despacho de la minoría se expresó que dicho precepto "solo se refiere al riesgo creado proveniente de una cosa, y no comprende por extensión al que resulta de la actividad riesgosa realizada sin intervención de cosas" (JA 1995-II-995). En contra de la interpretación amplia del art. $1113,2^{\circ}$ párrafo se han expresado Félix A. Trigo RePresas y Marcelo LóPez Mesa, Tratado de la responsabilidad civil, La Ley, Bs. As., 2004, t, III, ps. 333 y ss.

75 SCBA, L.44069, "Conti, Oscar v. Arias, Francisco s/indemnización por daños y perjuicios", sent. del 17/12/91, base de datos JUBA, sum. B.41.781.

76 LoRenzetTr, ob. cit., ps. $346 / 347$ y Galdós, ob. cit., p. 448.

77 Código Civil y normas complementarias..., cit., T. $3^{\mathrm{a}}$, ps.

78 ¿El riesgo creado suprimió el régimen de la culpa del Código Civil de Vélez Sarsfield?, cit., ps. 4751477 . 
vención activa de una cosa y el perjuicio no proviene de su riesgo o vicio. En estos supuestos rige una presunción iuris tantum de culpa del dueño o guardián. La responsabilidad es de base subjetiva, similar a la consagrada en el art. 1109 del Código Civil ya que cesa si el dueño o guardián demuestran que no fueron culpables $^{79}$.

b. Daños causado por el riesgo o vicio de la cosa $\left(2^{a}\right.$ parte del $2^{\circ}$ párrafo del art. 1113 del Código Civil). En estos casos el daño deriva del riesgo o vicio de la cosa. A diferencia del supuesto anterior, se trata de un caso de responsabilidad objetiva. No hay aquí una presunción de culpa sino de causalidad.

Como puede advertirse la distinción no es intrascendente, pues son diferentes las naturalezas y los requisitos que deben configurarse en ambos casos.

A pesar de ello, en los hechos la primera de las categorías mencionadas ha visto reducida sustancialmente su ámbito de aplicación.

\section{2) Reflexiones respecto de la responsabilidad estatal por riesgo}

En lo que concierne estrictamente a la responsabilidad estatal, el examen de fallos de diversos tribunales permite advertir aplicaciones inadecuadas de la teoría del riesgo, ya sea porque con ella se aprehenden supuestos que en verdad caen en el ámbito del factor falta de servicio $^{80}$, o porque se aplica el art. $1113,2^{a}$ parte, del Código Civil con un alcance desmedido que provoca la expansión excesiva del deber de reparar estatal ${ }^{81}$.

El mismo fenómeno de fuerza expansiva del riesgo creado que lo llevó a limitar significativamente y debilitar el campo de acción de la culpa en el derecho privado, también se aprecia en el ámbito de la responsabilidad estatal con relación a la falta de servicio, que constituye, como ya señalamos, el factor de atribución de mayor entidad.

En efecto, el casuismo jurisprudencial revela que muchos tribunales efectúan una aplicación muy generalizada del factor de atribución riesgo, desplazando incorrectamente el factor falta de servicio, de características muy diferentes.

79 Pizarro, Código Civil y normas complementarias..., cit., T. $3^{a}$, ps. 520/521

80 En este sentido ver la nota crítica que efectúa Armando N. Canosa al fallo de la Corte nacional "Pose", cit. (Nuevamente el artículo 1113 del Código Civil y la responsabilidad del Estado, ED, 157-84).

81 Conf. López Mesa, ob. cit., p. 463. 
Si bien en ambos supuestos no es preciso demostrar la culpa o dolo del funcionario ${ }^{82}$, la responsabilidad por falta no es una responsabilidad de resultados, sino de medios, de conductas. No basta demostrar el nexo causal y el daño para que el Estado responda por falta de servi$\mathrm{cio}^{83}$, sino que es menester acreditar el anormal o irregular comportamiento administrativo ${ }^{84}$, cuya determinación debe realizarse sobre la base de una apreciación en concreto que tome en cuenta la naturaleza de la actividad, los medios de que dispone la Administración, el lazo que une a la víctima con el servicio y el grado de previsibilidad del daño" 85 .

82 La culpa o dolo del funcionario no constituyen elementos determinantes de la responsabilidad estatal por falta de servicio, sino la falta del sistema o del aparato administrativo (Ver: Perrino, La responsabilidad de la Administración por su actividad ilicita, cic.). Por eso se afirma que la falta de servicio puede ser anónima e impersonal, pues no es preciso individualizar a su autor (DE LAubadère, André, Traité de Droit Administratif, huiieme édition, Librairie Genérale de Droit y Jurisprudence", París, 1980, p.721), y que se trata de una responsabilidad de base objetiva, ya que no es necesario indagar en la subjetividad del funcionario para que aquella se configure (CASSAGNE, Derecho Administrativo, t. I, ps. 503; 548/551 y Reflexiones sobre los factores de atribución en la responsabilidad del Estado por la actividad de la Administración, LL, supl. diario del 28/7/05; TAwIL, Guido S., La responsabilidad del Estado y de los magistrados y funcionarios judiciales por el mal funcionamiento de la Administración de justicia, Depalma, Buenos Aires, 1993, p. 109; MATA, Ismael, Responsabilidad del Estado por el ejercicio del poder de policía, obra colectiva Responsabilidad del Estado y del funcionario público, Ciencias de la Administración, Buenos Aires, 2001, p. 176; Mertehikian, Eduardo, La responsabilidad pública, Abaco, Buenos Aires, 2001, p. 63 y ss. y BONPLAND, Viviana M., Responsabilidad extracontractual del Estado (Análisis exegético de las citas del codificador al artículo 1112 del Código Civil), LL 1987-A-784 y 786). En cambio afirman el carácter subjetivo de la responsabilidad por falta: Hutchinson, Tomás, Los daños producidos por el Estado, Jus n ${ }^{\circ} 38$, p. 63 y ReIRIZ, María Graciela, Responsabilidad del Estado en la obra colectiva El Derecho Administrativo hoy, Ciencias de la Administración, Buenos Aires, 1996, p. 226.).

83 Esta característica de nuestro régimen de responsabilidad del Estado es común con lo que acontece en los sistemas francés, italiano y alemán (ver: Oriol Mir Puigpelat, La responsabilidad patrimonial de la Administración. Hacia un nuevo sistema, Civitas, Madrid, 2002, ps. 177/185 y 258/259) y lo distingue del modelo español en el cual el concepto de lesión y el criterio de la causalidad son los elementos determinantes para la obligación de indemnizar (Luis Martín Rebollo, Puntos de inflexión en la jurisprudencia sobre responsabilidad de la Administración Pública, trabajo inédito, año 2004).

De ahí que en un trabajo anterior hemos señalado que si bien no es preciso demostrar la culpa del funcionario para que sea viable el deber estatal de resarcir por falta de servicio, si lo es acreditar la falta o culpa del "sistema administrativo", la falta o culpa de la "organización administrativa" (La responsabilidad de la Administración por su actividad ilícita, cit.).

85 Causa "Zacarías, Claudio H. c/Provincia de Córdoba y otros", sent. del 28/4/98 (LL 1998-C, p. 317, con nota de Jorge Bustamante Alsina, Es responsable la Asociación del Fútbol Argentino por los daños que se generan en ocasión de las competencias que organizan sus entidades afiliadas, y en J.A t. 1999-I, p. 380, con nota de Félix A. Trigo Represas, El caso Zacarías: un fallo con importantes aportaciones, pero no obstante deficitario). 
Por otro lado, el estudio de los pronunciamientos judiciales ${ }^{86}$ también pone de relieve que en numerosas ocasiones se ha condenado al Estado en casos en los que, además de no generar la situación de daño, ni obtener ningún provecho o beneficio de la cosa productora del perjuicio, tampoco tenía ningún tipo de control o dominio sobre aquellas, ni medios para evitar la producción del perjuicio ${ }^{87}$.

\section{La Teoría del Riesgo y la Responsabilidad estatal derivada DE LA ACTIVIDAD DE LOS CONCESIONARIOS DE SERVICIOS Y DE OBRAS PÚBLICAS}

Un ámbito en el cual la aplicación de la teoría del riesgo, en los estrictos términos del art. $1113,2^{\circ}$ párrafo, $2^{\text {a }}$ parte del Código Civil,

86 En muchos pronunciamientos condenatorios del Estado parecen primar razones de índole humanitaria y no de índole jurídico.

87 Un buen ejemplo de lo dicho es el fallo de la Cámara Federal de Apelaciones de Córdoba en el cual, por mayoría, se condenó solidariamente al Estado Nacional con el autor material del daño a indemnizar la muerte producida, en el marco de una reyerta de vecinos, por un suboficial en retiro efectivo de la Armada con el sable que le fue entregado como parte del uniforme con motivo de su ascenso a suboficial segundo. Sustancialmente fueron tres los argumentos invocados. El primero de ellos, que la situación de retiro del victimario no implicaba la pérdida de su estado militar, con lo cual conservaba, aunque con algunas restricciones, los mismos derechos y deberes que el personal en actividad. Por otro lado, a fin de aplicar el art. $1113,2^{\mathrm{a}}$ parte del Código Civil, se sostuvo que en virtud del peculiar régimen jurídico del sable suministrado por la fuerza, no era posible afirmar que el victimario era su dueño exclusivo. Finalmente, se expresó que la Armada debía ser responsabilizada por incorporar a sus filas a una persona como el ofensor, al cual al momento de pasar a retiro le entregó el arma letal, sin percatarse del riesgo que creaba para terceros.

Con buen criterio, la Corte Suprema de Justicia de la Nación revocó dicho pronunciamiento. Para así decidir sostuvo que en el caso no mediaba nexo causal alguno entre el daño y la actividad estatal ya que el autor del homicidio estaba retirado y no prestaba en ese momento funciones para el Estado.

Respecto a la aplicación del art. $1113,2^{\mathrm{a}}$ parte el tribunal señaló que el sable formaba parte del uniforme de los suboficiales y que, de acuerdo a las reglamentaciones de vestuario, eran de su propiedad. Por ende, erea erróneo atribuir responsabilidad al Estado por la indebida utilización de una cosa de la que no era su dueño ni estaba bajo su guarda ya que no tenía el manejo ni el empleo de ella.

De todos modos, el tribunal expresó que, aun cuando se entendiera que el sable era de propiedad del Estado, la solución no se modificaría porque en el caso se lo habría usado en contra de la voluntad del dueño (art.1113, $3^{\circ}$ párrafo del Código Civil), lo cual excluiría la responsabilidad estatal.

Finalmente, la Corte descartó, en atención a las constancias obrantes en el legajo personal del autor material del homicidio, la existencia de culpa in eligendo de la Armada y -entendió que la entrega del sable al homicida no fue la causa adecuada de la muerte, según el curso natural y ordinario de las cosas, razón por la cual el Estado no debía responder. Causa "Deoca, Corina del Rosario el Paredes, Fidel Leónidas y Estado Nacional (M. de Defensa de la Nación)", sent. del. 30/5/01, Fallos: 324:1701). 
produce relevantes consecuencias, ya que expande el deber de reparar del Estado y modifica el principio rector que impera en este ámbito, es el de la responsabilidad ocasionada por los concesionarios de servicios públicos y de obras públicas ${ }^{88}$.

En efecto, por no estar insertados en los cuadros de la Administración, por regla no puede atribuirse responsabilidad al Estado por los daños derivados de sus contratistas. De ahí que, en principio, no puede comprometer la responsabilidad de la Administración la actividad dañosa de los concesionarios de servicios y de obras públicas ${ }^{89}$.

Por los perjuicios que deriven del ejercicio de la concesión responde en forma directa el concesionario. Ello es así, porque el concesionario no es un órgano estatal y tampoco un dependiente del Estado, sino una persona jurídica distinta que actúa per se, a su cuenta y a riesgo ${ }^{90}$, tal como lo disponen la generalidad de los marcos regulatorios. El resarcimiento de los perjuicios está comprendido en el riesgo propio de la concesión. Por lo demás, la privatización de los servicios públicos implica no solo el traslado de la gestión de la actividad sino también la de los costos que deben sufragarse por los daños derivados de la prestación ${ }^{91}$. Como se ha expresado, la idea misma de la concesión responde al deseo de separar de la organización propia de la Administración (no en vano la concesión es una forma de gestión indirecta de servicios) la atención de algunas necesidades de interés general ${ }^{92}$.

De ahí que, deviene razonable concluir que la traslación de prestaciones a los concesionarios mediante la técnica concesional ha importado, tal como lo determinan la generalidad de los marcos regulatorios de servicios públicos, que sean estos quienes deben hacerse cargo de las indemnizaciones que antes correspondía al Estado sufragar ${ }^{93}$.

88 Ver: Perrino, Pablo E., La responsabilidad del Estado y de los concesionarios derivada de la prestación de servicios públicos privatizados, obra colectiva Contratos administrativos, Ciencias de la Administración, Buenos Aires, 2000, ps. 167/169

Cassagne, ob. cit., t. I, p. 562; Comadira, Julio R., Derecho Administrativo. Acto administrativo. Procedimiento administrativo. Otros estudios, $2^{a}$ ed. act. y ampl., Buenos Aires, 2003, p. 374; Pérez Hualde, Alejandro, El concesionario de servicios públicos privatizados. La responsabilidad del Estado por su accionar, Depalma, Buenos Aires, 1997, p. 55 y ss.; FARrando, Ismael, La responsabilidad de los prestadores en los marcos regulatorios, publicado en la obra colectiva Servicios públicos, Dike, Mendoza, 2001, ps. 180 y ss.; Bustelo, Ernesto N., Responsabilidad del Estado por la actividad u omisión de los entes reguladores de los servicios públicos privatizados, publicado en la obra colectiva Servicios públicos, Dike, Mendoza, 2001, ps. 442/443 y PERRINo, La responsabilidad del Estado y de los concesionarios .... cit., p. 163).

90 Sarmiento García, Jorge, Concesión de servicios públicos, $2^{a}$ ed., Ciudad Argentina, Mendoza, 1999, p. 269.

91 Perrino, La responsabilidad del Estado y de los concesionarios ..., cit., p. 163 y ss.

92 MuÑoz Machado, Santiago, La responsabilidad civil concurrente de las Administraciones Públicas, Civitas, Madrid, 1992, p. 132/133.

93 Gordillo, Agusrín A., Tratado de Derecho Administrativo, T. II, $6^{a}$ ed., Fundación de Derecho Administrativo, Buenos Aires, 2003, cap. XX, p. 8 y ss. 
Ahora bien, el principio indicado parece encontrar una relevante excepción en el supuesto de perjuicios ocasionados por concesionarios mediante bienes de propiedad estatal afectados a la concesión.

Téngase presente que en numerosas concesiones de servicios públicos el Estado transfirió bienes de su titularidad al concesionario en condición de tenedor ${ }^{94}$.

También en los contratos de concesión de obras viales por peaje existen cláusulas en las que se determina que el concedente conserva el dominio de los terrenos y bienes de su propiedad que pone a disposición de la concesionaria, a la que se le transfiere su tenencia y custodia ${ }^{95}$.

Como se comprenderá, la aplicación del art. $1113,2^{\circ}$ párrafo, $2^{a}$ parte del Código Civil en los casos de daños ocasionados por dichos bienes tornaría irremediablemente responsable al Estado concedente.

Frente a dicha situación y ante la ausencia de regulaciones legislativas que eximan al Estado del deber de responder en tales supuestos, en algunos pliegos de bases y condiciones y en contratos de concesión ${ }^{96}$ se ha previsto expresamente que, como regla, el concesionario es el responsable ante el Estado y los terceros por todos los daños provocados por la administración de los bienes afectados al servicios y por todos los riesgos y las obligaciones contractuales y extracontractuales inherentes a su operación, administración, mantenimiento, adquisición y construcción.

Asimismo, se ha establecido que el concesionario deberá hacerse cargo de cualquier acción que se ejerza contra la concedente en virtud de la responsabilidad extracontractual del Estado fundada en la potestad para la prestación de los servicios públicos y del pago de las indemnizaciones que ello diere lugar, como asimismo las que surgieren por daños causados a terceros o a sus bienes como consecuencia en ambos casos del obrar de la concesionaria o de las responsabilidades que le son propias en su carácter de prestador de servicios públicos y concesionaria. También se determina que el concedente debe citar como tercero interesado a la concesionaria, la que estará obligada a intervenir en la causa que se origine y garantizar al concedente por el resultado del pleito, debiendo reintegrarle cualquier suma que por cualquier concepto

94 Vgr, cláusula 9.2.2. del contrato de concesión del Ferrocarril Transportes Metropolitanos General San Martín S. A., cláusula 6.2.1 del contrato de concesión de Aguas Argentinas, etc.

95 Cláusula 16.1 de los contratos de accesos a la ciudad de Buenos Aires.

96 Ver: Pliego de bases y condiciones para la concesión del servicio de agua, aprobado por la Secretaría de Obras Públicas y Comunicaciones 186/92 contratos de concesión de obra vial de acceso a Buenos Aires (art. 16.8 de los contratos de concesión de obras de los accesos a Buenos Aires). 
el Estado se viera obligado a pagar o a la que fuera condenado en tales circunstancias.

Según puede apreciarse, la obligación del concesionario de presentarse en el pleito como tercero a fin de asumir el pago de las erogaciones efectuadas por el concedente se establece a fin de mitigar los efectos que derivan de la aplicación del régimen de responsabilidad establecido en la legislación civil.

\section{Colofón: Necesidad de limitar el CAMPo DE ACCión DEL FACTOR DE ATRIBUCIÓN RIESGO}

En nuestro parecer no corresponde aplicar en forma directa y sin cortapisa alguna el art. $1113,2^{\circ}$ párrafo, $2^{a}$ parte del Código Civil, establecido para regular un supuesto específico de responsabilidad civil entre sujetos privados, a un ámbito sensiblemente diferente como es el de la responsabilidad de derecho público del Estado ${ }^{97}$, en el cual su aplicación debe efectuarse mediante la técnica de la analogía ${ }^{98}$, lo

97 Miguel S. MARIENHOFF con toda claridad expresaba: "la responsabilidad "extracontractual" del Estado, cuando este actúa en el ámbito del derecho público, se rige, substancialmente por normas o principios de derecho público, y no por normas o principios de derecho civil. De ahí que el Código Civil no tenga aplicación en tal caso. Ya el Dr. Dalmacio Vélez SARSFIEld advirtió que en el Código Civil solo se legisla sobre el derecho privado (nota al art. 31)" (Responsabilidad "extracontractual" del Estado por las consecuencias dañosas de su actividad "lícita" desplegada en el ámbito del derecho público (a propósito de un fallo de la Corte Suprema de Justicia de la Nación, ED, 167-965).

98 Así lo ha resuelto la Corte Suprema de Justicia de la Nación en numerosas ocasiones (causas "Cipollini, Juan Silvano c/ Dirección Nacional de Vialidad y otra" 2/3/78, Fallos: 300:143; "El Panamericano S.A.C.I. y F, cl Nación Argentina" 27/5/82, Fallos:304:721; "Mengual, Juan y otra c/ Estado Nacional (M de Defensa EMGE.)", sent. del 19/10/95, Fallos: 318:1959; "S.A. Organización Coordinadora Argentina c/ Secretaría de Inteligencia de Estado", sent. del 17/2/98, Fallos: 321: 174; conf. CASSAGne, Derecho Administrativo, cit. t. I, p. 145; Sarmiento García, Jorge H, Responsabilidad del Estado en la Provincia de Mendoza, obra colectiva Responsabilidad del Estado y del funcionario público, Ciencias de la Administración, Buenos Aires, 2001, p. 381 y ss.). Es que el derecho administrativo constituye una disciplina jurídica autónoma que se autointegra, en tanto se nutre de su propio sistema de normas y principios que difieren en muchos casos de los del derecho privado (Martín Retortillo-Baquer, Sebastían, El Derecho civil en la génesis del derecho Administrativo $y$ de sus instituciones, $2^{\mathrm{a}}$ ed. ampliada, Civitas, Madrid, 1996, p. 36; conf. García de EnTERría, Eduardo y Fernández, Tomás Ramón, Curso de Derecho Administrativo, T. I, $6^{a}$ ed., Madrid, 1993, p. 40). En este sentido Renato AlEssi escribe: "La contraposición entre Derecho administrativo y Derecho privado, no debe por otra parte entenderse en el sentido de que el Derecho administrativo constituya un conjunto de normas excepcionales, un sistema jurídico especial, frente al jus commune representado por el Derecho civil. Por el contrario, el Derecho administrativo, respecto a un determinado conjunto de relaciones (precisamente aquellas inherentes al desarrollo de la función administrativa), constituye él mismo un jus commune, es decir un sistema jurídico autónomo, paralelo al Derecho privado. De este hecho se derivan importantes consecuencias: a) en el caso de 
cual no autoriza a generalizar los principios del derecho privado para comprender situaciones distintas de las contempladas para situaciones muy diversas 99 .

Ello es así, porque las reglas del régimen de la responsabilidad civil, además de diferir en sus fines ${ }^{100}$ y fundamentos ${ }^{101}$ respecto de la responsabilidad estatal, no contemplan la singular posición de la Administración Pública en cuanto titular de prerrogativas asignadas para el logro del bien común, ni la complejidad del obrar estatal y sus consecuencias.

Por lo demás, como señala Cassagne "mientras en el Derecho Civil la responsabilidad mira fundamentalmente el lado de la víctima que sufre daños injustos y la consecuente restitución conforme a criterios pertenecientes a la justicia conmutativa, el Derecho Público (Constitucional y Administrativo) tiene en cuenta los intereses de la víctima, armonizándolos con los del Estado y los ciudadanos, es decir, atiende a las relaciones entre el individuo que padece el perjuicio y la comunidad"102.

Los reparos expuestos a la forma que se aplica el art. $1113,2^{\circ}$ párrafo, $2^{a}$ parte del Código Civil al campo estatal no significa que estemos postulando que debamos eliminar el factor de atribución riesgo como generador del deber de responder del Estado, sino limitar su utilización a los supuestos específicos en los que se reúnan sus presupuestos, máxi-

que existan lagunas en el ordenamiento positivo administrativo, no serán aplicables las normas contenidas en el ordenamiento privado, ni directamente ni por analogía, sino que deberán aplicarse por analogía otras normas contenidas en el ordenamiento administrativo o bien los principios generales. b) a su vez, los principios generales a aplicar en tales casos no deberán extraerse del conjunto del ordenamiento privado, sino exclusivamente del público, constituido por el propio Derecho administrativo. c) finalmente, la interpretación de las normas del Derecho administrativo no debe ir ligada necesariamente a los principios que regulan la interpretación de las normas del Derecho privado, pudiendo regirse por principios peculiares del Derecho administrativo, de naturaleza exclusivamente pública". (Instituciones de Derecho Administrativo, T. I, traducción de la $3^{a}$ ed. italiana por Buenaventura Pellisé Prats, Bosch, Barcelona, 1970, p. 15).

99 Hutchinson, Tomás, Breves análisis de la responsabilidad del Estado por accidentes de tránsito, cit, p.325.

100 La responsabilidad estatal tiene múltiples finalidades pues, además, de operar como instrumento de garantía patrimonial, también cumple funciones preventivas, de control y docencia respecto de los funcionarios públicos (conf.: MARTín ReBollo, Luis, Los fundamentos de la responsabilidad del Estado, obra colectiva citada Responsabilidad del Estado y del funcionario público, Ciencias de la Administración, Buenos Aires, 2001, p. 21; Cassagne, Derecbo Administrativo, cit., T. I, p. 566).

101 Cassagne, Juan Carlos, Las grandes lineas de la evolución de la responsabilidad patrimonial del Estado en la jurisprudencia de la Corte Suprema, LL 2000-D-1219.

102 Derecho Administrativo, cit. t. I, p. 552. 
me que su aplicación desmedida o extrema puede convertir al Estado, dada la vastedad de las cosas que están bajo su guarda o son de su propiedad, en una especie de asegurador universal de todos los riesgos que depara la vida en sociedad ${ }^{103}$, lo cual es inadmisible ${ }^{104}$.

103 Esta opinión también ha sido sostenida sólidamente desde el Derecho Privado, aunque solitariamente, por López Mesa quien ha escrito: “la aplicación desmesurada del art, 1113 del Código Civil a supuestos que ontológicamente le son ajenos ha extendido ad infinitum. el ámbito de la obligación del Estado de reparar daños sufridos por los particulares" (ob. cit., p. 435).

104 Conf. CASSAGNE, Reflexión sobre los factores de atribución..., cit.; Hutchinson, Tomás, Breves análisis de la responsabilidad del Estado por accidentes de tránsito, cit. p. 326. 